\title{
İlkokul Öğrencilerinin Değişen Davranış, Kişilik ve Tutum Özelliklerinin İncelenmesi
}

\section{Investigation of Changing Behaviour, Personality and Attitude Characteristics of Primary School Students}

Özgür Babayiğit ${ }^{a^{*}}$

a Dr. Öğr. Üyesi, Yozgat Bozok Üniversitesi, Eğitim Fakültesi, Temel Eğitim Bölümü, 66100, Yozgat/Türkiye. ORCID: 0000-0001-6123-0609

\section{MAKALE BİLGİSI}

\section{Makale Geçmişi:}

Başvuru tarihi: 11 Eylül 2018

Düzeltme tarihi: 30 Ekim 2018

Kabul tarihi: 13 Kasım 2018

\section{Anahtar Kelimeler:}

Değişim

İlkokul

Öğrenci

\section{ARTICLE INFO}

\section{Article history:}

Received 11 September 2018

Received in revised form 30 October 2018

Accepted 13 November 2018

\section{Keywords:}

Change

Primary school

Student

\section{ÖZ}

$\mathrm{Bu}$ araştırmanın amacı ilkokul öğrencilerinin değişen davranış, kişilik ve tutum özelliklerinin incelenmesidir. Araştırma, nitel araştırma yöntemlerinden birisi olan fenomenoloji yöntemiyle gerçekleştirilmiştir. Araştırmanın katılımcılarını Yozgat il merkezindeki bir ilkokulda görevli 17 sınıf öğretmeni oluşturmaktadır. Veri toplama aracı olarak yarı yapılandırılmış görüşme formu kullanılmıştır. Veriler 2018 yılı mayıs ayında toplanmıştır. Yarı yapılandırılmış görüşme formu ile birlikte 17 sınıf öğretmeniyle görüşmeler yapılmıştır. Verilerin analizinde içerik analizi kullanılmıştır. Araştırma sonucunda ilkokul öğrencilerinin teknoloji kullanma becerilerinde artış, özgüven artışı, öğrenme kapasitelerinde artış tespit edilmiştir. Ancak saygı ve sevgide azalma, sosyalleşmede problemler, benmerkezcilik, sorumluluk bilincinde azalma belirlenmiştir.

\section{Giriş}

Toplumlar yaşantıları, tecrübeleri, bilim, teknoloji, inanış gibi nedenlerle sürekli olarak bir değişim içerisindedir. Bu değişim tüm bireyleri etkilediği gibi, kuşkusuz ilkokul öğrencilerini de etkilemektedir. Diğer öğrenim seviyelerindeki öğrenciler gibi ilkokul öğrencileri de televizyon, bilgisayar, internet, cep telefonu gibi araçları sıklıkla kullanmaktadır. $\mathrm{Bu}$ araçları kullanma durumu ise ilkokul öğrencilerini etkilemekte, onların düşünce yapılarını değiştirmektedir. Bilgi çağının çocuklarını ve yarının yetişkinlerini oluşturacak olan ilkokul öğrencilerinin düşünce yapılarının ve farklı özelliklerinin ortaya çıkarılması son derece önemlidir. Yapılan bu araştırma ile günümüz ilkokul öğrencilerinin davranış, kişilik, tutum özellikleri, düşünce yapıları, belirgin özellikleri betimlenmeye çalışılmıştır. Öncelikle toplumsal değişim ve eğitim konusu üzerine durulmuş, daha sonra özelde ise günümüz ilkokul öğrencilerinin genel özellikleri açıklanmıştır.

Değişen toplumlarda eğitim kültürü aktarmanın yanı sıra yeni nesilleri değişimlere de hazırlamaktadır (Erol, 2011: 109110). Toplum eğitimi değişime zorlamakla birlikte, eğitim toplumun değişimini sağlayan unsurlardan biridir. Eğitim, bu faaliyeti gerçekleştiren en önemli araçtır (Prensky, 2001: 4; Fidan ve Fidecioğlu, 2010: 146-147). Bilgi teknolojileri, toplumlar üzerinde büyük bir etkiye sahiptir. Bilgi çağına uygun, bilgi toplumuna özgü özellikler dikkate alınarak bireyleri yetiştirmek zorunluluğu ortaya çıkmaktadır (Monereo, 2004: 46; Aydın, 2003: 183-184). Bunun yanı sıra, eğitimden beklentiler de çeşitlenmektedir. Küreselleşen dünyada eğitimden, küresel ekonomi için gerekli olan insan gücünü yetiştirmesi hedeflenmektedir(Can, 2015: 251). Ayrıca eğitim, bireyin toplumla uyum içinde yaşaması

* Sorumlu yazar/Corresponding author

e-posta: ozgur.babayigit@ bozok.edu.tr 
açısından da önem kazanmaktadır. Eğitim etkinliği, toplumların gelişmesinin temeli olarak görülmektedir(Fidan ve Fidecioğlu, 2010: 146).

Gelişmiş toplumlar değişen toplumlar olduğu için, toplumsal değişmeler eskiye oranla çok daha fazla ve hızlı olmaktadır. Değişen toplum eğitimin işlev ve yapılarını değişmeye zorlamaktadır (Erol, 2011: 117). Günümüzde, hızlı bir değişim ve dönüşüm, eğitim alanında farklı değişmeleri zorunlu hale getirmektedir. Bilgi tabanlı değişim hareketleri bireylerin eğitimden beklentilerini değiştirmektedir (Parlar, 2012: 194). Toplumundaki değişimin eğitime yansıdığı, eğitimi de değiştirdiği görülmektedir.

Gelişmiş toplumlarda bilgisayar etkili bir iletişim aracı haline gelmiştir. $\mathrm{Bu}$ sebeple bilgisayar temelli eğitimi kullanmak zorunlu olmaktadır (Gündoğar, 2014: 121). Bilgisayarın yanı sıra, televizyon çocuğa ses, renk, yazı unsurlarıyla çocuğun ilgi-kabul çıtasını yükseltmektedir. Çocuk daha sonra bu kadar etkili olmayan uyarıcılara ilgi göstermemekte veya ilgisini çok kısa sürede kaybetmektedir (Yılmaz, 2012: 121). Twitter, facebook, bilgisayar, cep telefonu, etkileşimli tahta, internet gibi yirmi birinci yüzyıl teknoloji araç ve ortamları öğrencilere; zengin görseller ile dikkat toplama, derse bağlılıkta artış, bilgiye kolay ve hızlı şekilde erişim sağlama, eğlenerek öğrenme, öğrenme zamanının etkin kullanımı, yaşam boyu öğrenme gibi faydalar sunmaktadır (Boyd ve Ellison, 2007: 212; Prensky, 2009: 3; Günüç, Odabaş1 ve Kuzu, 2013: 437-438;).Televizyon izleme, bilgisayar kullanımı, cep telefonu kullanımı gibi işlemler beynin farklı kimyasal tepkimelerde bulunmasına, sosyal-kültürel değerler ve beklentiler oluşturmalarına sebep olmaktadır. Günümüz öğrencileri sadece farklı şeyler düşünmekle kalmamakta, bunun yanı sıra farklı düșünmekle birlikte farklı düşünme yolları kullanmaktadırlar (Jones, 2000: 37-39; Şahin, 2009: 161;Tompkins, 2007: 18; White ve Castello, 2008: 96).Günümüzdeki ilkokul öğrencileri kendini iyi ifade edebilen, sorgulayan, çok yönlü, kolay benimsemeyen, detaylı düşünen kişilerdir. Günümüzde öğrenciler pasif öğrenen olmak istememektedir (Gündoğar, 2014: 122). Günümüz ilkokul öğrencisinin özellikleri incelendiğinde, teknoloji kullanımı ve kişisel özelliklerindeki farklılıklar dikkat çekmektedir.

Pedró (2006: 10-13) tarafından yapılan araştırma sonucunda günümüz öğrencilerinin özellikleri üç ana başlık altında toplanmıştır. Bunlar: 1. Alternatif bilişsel beceriler. 2.Kültürel uygulamalar ve sosyal değerlerdeki değişimler. 3 . Öğretim ve öğrenmeye ilişkin beklentiler.

1. Alternatif bilişsel beceriler:

- Özellikle basılı olmayan dijital kaynaklara erişme.

- Metin üzerinde imge, hareket ve müzik önceliği vermek.

- Çok görevli işlemlerle rahat hissetmek.

- Durdurulan, doğrusal olmayan bilgi işleme yoluyla bilgi edinmek.

2.Kültürel uygulamalar ve sosyal değerlerdeki değişimler:

- İnternetin daha fazla sosyalleşme imkanı sunmasına karşın, fiziksel izolasyon ve yalnızlık artmıştır.

- Önceleri dinlenmeye ayrılan süre, günümüzde bilgisayar ve internet ile geçirilmektedir.

- Bireyler arası iletişimde kısa sürede yanıt verme alışkanlık olmuştur.

- Çoklu ortamlar, yazılı ürünlerden daha değerlidir.
- Yazma alışkanlıkları, yeni diller meydana getirecek kadar değişime ve özellikle kısaltmaya uğramıştır. Cep telefonlarında kullanılan kısaltma dili, yaşamın diğer alanlarına yayılarak kısaltma dili oluşmuştur.

3. Öğretim ve öğrenmeye ilişkin beklentiler. Günümüz öğrencilerinin aşağıda belirtilen konularda eğitimden ve okullardan yüksek beklenti içerisinde olduğu düşünülmektedir.

- Okullarda sunulan bilgi iletișim teknolojileri cihaz ve hizmetleri türü.

- Kullanılan bilgi iletişim teknolojileri araçlarının türleri.

- Bilgi iletişim teknolojileri kullanım sıklıkları.

- Etkinliklerin çeşitliliği.

- Birlikte çalışma ve sosyal ağ kurma firsatları.

- Öğrenmenin bireyselleştirilmesi.

- Kullanılan bilgi iletişim teknolojileri araçlarının çoklu ortam ve etkileşimlilik bakımından kalite standartları.

Davranış, kişilik ve tutum konuları ile ilgili bazı temel kavramları tanımlamakta fayda bulunmaktadır. Öz güven, bireyin belirli bir aktiviteyi başarılı bir şekilde yerine getireceğine yönelik inancı ve bireyin kendi yarg1, yetenek, güç ve kararlarına güvenmesi demektir (Feltz, 1988: 423).Sayg1; değeri, üstünlüğü, yaşlılığı, yararlılığı, kutsallığ1 dolayısıyla bir kimseye, bir şeye karşı dikkatli, özenli, ölçülü davranmaya sebep olan sevgi duygusu, hürmet, ihtiram demektir (Türk Dil Kurumu, 2018).

Konu ile ilgili olarak yapılan araştırmalar incelenirken 2010 yılı alt sınır olarak kabul edilmiştir. Can (2015), Erol (2011), Fidan ve Fidecioğlu (2010), Gündoğar (2014), Günüç, Odabaşı ve Kuzu (2013), Parlar (2012), Yılmaz (2012) tarafından çeşitli araştırmalar yapılmıştır. Bilgi çağını yaşadığımız günümüzde, toplumlar hızla değişmektedir. $\mathrm{Bu}$ değişim hiç kuşkusuz ilkokul öğrencilerini de kapsamaktadır. Yapılan bu araştırma ile günümüzdeki ilkokul öğrenci özellikleri açıklanmaya, betimlenmeye çalışılmıştır. Ortaya konulan bulgular ile öğretim programlarını hazırlayan uzmanlara, Milli Eğitim Bakanlığına, çocuk gelişimi uzmanlarına, sınıf öğretmenlerine ve velilere 1 şık tutması açısından önemlidir. Katılımcı sınıf öğretmenlerinin görüşme sorularına içtenlikle ve samimiyetle cevap verdikleri varsayılmıştır. Bu araştırma 2018 yılı mayıs ayında Yozgat il merkezindeki bir devlet ilkokulunda görev yapan 17 sinıf ögretmeni ile sınırlıdır.

$\mathrm{Bu}$ araştırmanın genel amacı ilkokul öğrencilerinin değişen profillerinin incelenmesidir. Bu genel amaç doğrultusunda, sınıf öğretmenlerinin 2000 yılından önceki ilkokul öğrencileri ile günümüz yani 2018 yılı ilkokul öğrencilerini kıyaslamaları istenmiştir.

\section{Yöntem}

Bu bölümde çalışmanın deseninden, çalışma grubundan, veri toplama aracindan, verilerin toplanmasından, verilerin analizinden ve geçerlikten-güvenirlikten bahsedilmektedir.

\subsection{Araştırma Deseni}

$\mathrm{Bu}$ araştırma nitel araştırma yöntemlerinden birisi olan fenomenoloji yöntemiyle yapılmıştır. Fenomenoloji birkaç kişinin bir fenomen veya kavramla ilgili yaşanmış deneyimlerinin ortak anlamını tanımlamaktadır (Creswell, 
2013: 77). Fenomenoloji deseni farkında olunanfakat derinlemesine ve ayrıntılı bir anlayışa sahip olunmayan olgulara odaklanmaktadır (Yıldırım ve Şimşek, 2006: 72).Fenomenoloji insanların fenomenleri nasıl tecrübe ettiklerinin metodolojik, özenli ve derinlemesine resmedilmesi ve betimlenmesidir (Patton, 2014: 104; Gliner, Morgan ve Leech, 2015: 97; Fraenkel, Wallen ve Hyun, 2011: 432). Başka bir tanımla fenomonoloji, bir fenomenin bireylerin ya da belli bir grubun deneyimleri açısından tanımlanmasıdır (Christensen, Johnson ve Turner, 2015: 408). Yapılan bu araştırmada fenomenoloji türlerinden deneysel (aşkın ya da psikolojik) fenomenoloji türü tercih edilmiştir. Deneysel (aşkın veya psikolojik) fenomenolojisi araştırmacının yorumlarına daha az ve katılımcıların deneyimlerinin betimlenmesine daha fazla vurgu yapmaktadır (Creswell, 2013: 80). Deneysel (aşkın ya da psikolojik) fenomenoloji bireysel deneyimin temel anlamlarını araştırmaktadır (Patton, 2014: 104). Bu bağlamda çalışmada üzerine odaklanılan olgu mevcut ilkokul öğrencilerinin, 2000'li yıllardaki ilkokul öğrencilerinden farklılık gösteren davranış, kişilik ve tutum özellikleridir. Kısaca bu araştırmadaki olgu değişimdir.

\subsection{Kat1limcilar}

İlkokul öğrencilerindeki değişimi en iyi gözlemleyen kişilerin sınıf öğretmenleri olduğu düşünülmektedir. Sınıf öğretmenlerinin bu konudaki görüş ve deneyimlerinin belirlenmesi için en uygun araştırma yönteminin fenomenoloji yöntemi olması nedeniyle, bu araştırmada fenomenoloji yöntemi kullanılmıştır. Katılımcıların belirlenmesinde uygun örnekleme yöntemi ile ölçüt örnekleme yöntemi kullanılmıştır (Büyüköztürk, Kılıç Çakmak, Akgün, Karadeniz, Demirel, 2012: 92). Uygun örnekleme yöntemi, zaman, para ve çaba tasarrufu yapmak için kolay olanı yapmak demektir (Patton, 2014: 244).Ölçüt örnekleme yöntemindeki temel anlayış, önceden belirlenmiş bir dizi ölçütü karşılayan bütün durumların çalışılmasıdır (Yıldırım ve Şimşek, 2006: 112). Ölçüt örneklem, belli ölçütleri sağlayan tüm durumları seçmek demektir (Patton, 2014: 243). Araştırmanın katılımcıları, Yozgat il merkezinde bir devlet ilkokulunda görev yapan 17 sinıf öğretmeninden oluşmaktadır. Katılımcıların belirlenmesinde ölçüt olarak öğretmenlikteki hizmet süresinin en az 20 yıl olarak belirlenmiştir. $\mathrm{Bu}$ ölçütün belirlenmesindeki amaç, hizmet y1lı fazla olan sınıf öğretmenlerinin deneyim, tecrübe ve gözlemleri sonucunda geçmiş ile günümüzdeki durumu daha iyi kıyaslayabilmeleridir. Katılımcı sınıf öğretmenlerinin demografik özellikleri Tablo 1'de belirtilmiştir.

Tablo 1. Katılımcı Sınıf Öğretmenlerinin Demografik Özellikleri

\begin{tabular}{lrr}
\hline Demografik Bilgiler & $\mathrm{n}$ & $\%$ \\
\hline Mesleki k1dem & & \\
\hline $20-25$ y1l & 6 & 35 \\
$26-30$ y1l & 3 & 18 \\
$31-35$ y1l & 1 & 6 \\
$36-40$ y1l & 6 & 35 \\
$41-45$ y1l & 1 & 6 \\
\hline Yaş & & \\
\hline $40-45$ & 4 & 23 \\
$46-50$ & 4 & 23 \\
$51-55$ & 2 & 12 \\
$56-60$ & 4 & 24 \\
\hline
\end{tabular}

\begin{tabular}{crr}
\hline $61-65$ & 3 & 18 \\
\hline Cinsiyet & & \\
\hline Kadın & 5 & 29 \\
Erkek & 12 & 71 \\
\hline Toplam & 17 & 100 \\
\hline
\end{tabular}

Tablo 1 incelendiğinde, katılımcıların meslekteki kıdemleri incelendiğinde, 20-25 yıl aras1 altı öğretmen; 26-30 y1l aras1 üç öğretmen; 31-35 yıl arası bir öğretmen; 36-40 yıl arası alt1 öğretmen; 41-45 yıl arası bir öğretmen olduğu görülmektedir. Katılımcıların yaşları incelendiğinde40-45 yaş arası dört öğretmen; 46-50 yaş arası dört öğretmen; 51-55 yaş arası iki öğretmen; 56-60 yaş arası dört öğretmen; 61-65 yaş arası üç öğretmen olduğu görülmektedir. Katılımcı sınıf öğretmenlerinin beşi kadın, on ikisi erkektir. Görüşme yapılan erkek sınıf öğretmenlerinin sayısı, kadın öğretmenlerin sayısının iki katından fazladır.

\subsection{Veri Toplama Arac1}

$\mathrm{Bu}$ araştırmada veri toplama aracı olarak yarı yapılandırılmış görüşme formu kullanılmıştır. Yarı yapılandırılmış görüşme formu yaklaşımı, görüşme sırasında görüşmeciye yöneltilecek bir sorular veya konular listesini kapsamaktadır (Yıldırım ve Şimşek, 2006: 122). Yarı yapılandırılmış görüşme formu, konuşma süresince farklı sorularla konunun açılmasına, çeşitli boyutların ortaya çıkmasına ve konu hakkında yeni fikirlere ulaşılmasına yardım etmektedir (Merriam, 2013: 88). Yarı yapılandırılmış görüşme formu oluşturulurken öncelikle konu ile ilgili alan yazın incelenmiştir. Alan yazın incelenmesinden sonra oluşturulan yarı yapılandırılmış görüşme formu, eğitimde ölçme ve değerlendirme konusunda uzman bir öğretim üyesine sunulmuştur. Daha sonra sınıf öğretmenliği alanında uzman bir öğretim üyesinin görüşüne sunulmuştur. Uzman görüşlerinin ardından yarı yapılandırılmış görüşme formunda çeşitli düzenlemeler yapılmıştır. Ardından, yarı yapılandırılmış görüşme formu pilot görüşme olarak iki sınıf öğretmenine uygulanmıştır. Pilot görüşmeler sonrasında yarı yapılandırılmış görüşme formuna son şekli verilmişstir. Yarı yapılandırılmış görüşme formu iki bölümdür. İlk bölümde sinıf öğretmenlerinin demografik özelliklerine yönelik sorular bulunmaktadır. İkinci bölümde ise ilkokul öğrencilerinin değişen profillerini belirlemeye yönelik sorular yer almaktadır. Bu sorular şunlardır:

1.İlkokul öğrencilerinin değișen profilleri, özellikleri, kişilik ve karakterleri hakkında neler düşünüyorsunuz?

2.Geçmiş yıllardaki ilkokul öğrencileri ile günümüzdeki ilkokul öğrencileri arasındaki farklılıklar nelerdir?

3.Geçmiş y1llardaki ilkokul öğrencileri ile günümüzdeki ilkokul öğrencilerini teknoloji kullanımı, öğrenme kapasiteleri, okula ve öğretmene karşı saygı ve sevgi yönünden vb. karşılaştırır mısınız?

\subsection{Verilerin Toplanmas1}

Fenomenoloji araştırmalarında başlıca veri toplama aracı görüşmedir (Christensen, Johnson ve Turner, 2015: 409; Gliner, Morgan ve Leech, 2015: 97; Yıldırım ve Şimşek, 2006: 74). Veriler 2018 yılı mayıs ayında toplanmıştır. Yarı yapılandırılmış görüşme formu ile birlikte, 17 sınıf öğretmeniyle görüşmeler yapılmıştır. Yapılan görüşmeler, izin alınarak ses kayıt cihazına kaydedilmiştir. Görüşmeler, 
sınıf öğretmeninin görevli olduğu sınıfta, teneffüslerde gerçekleştirilmiştir. Her bir görüşme ortalama 9 dakika sürmüştür. Yarı yapılandırılmış görüşme formundaki görüşme soruları öncelikle kısaca sınıf öğretmenine açıklanmıştır. Daha sonra yarı yapılandırılmış görüşme formunda yer alan sorular sırayla görüşme yapılan sınıf öğretmenine sorulmuştur. Yapılan görüşmeler, toplamda 162 dakika sürmüştür.

\subsection{Verilerin Analizi}

Fenomenoloji araştırmalarında veri analizi, yaşantıları ve anlamları ortaya çıkarmaya yöneliktir (Yıldırım ve Şimşek, 2006: 75). Verilerin çözümlenmesinde içerik analizi kullanılmıştır. İçerik analizinde veriler kodlandıktan sonra, veriler içinde tema ve örüntüler aramak için analitik tekniklere başvurulmaktadır (Glesne, 2012: 255). Ses kayıt cihazına kaydedilen görüşmeler, araştırmacı tarafından bilgisayarda yazıya geçirilmiştir. Yazıya dökülen görüşler birden fazla kez okunduktan sonra kodlamalar yapılmıştır. Kodlardan alt temalara, alt temalardan temalara ulaşılmıştır (Creswell, 2013: 82).İçerik analizi sürecinde öncelikle anahtar ifadeler listelenmiştir. Bir sonraki adımda araştırmacı bu önemli ifadelerden hareketle temalar içinde anlam kümeleri, grupları geliştirmiştir. Daha sonra bu önemli açıklamalar ve temalar, katılımcıların deneyimlerine ilişkin betimleyici olarak kullanılmıştır (dokusal betimleme).Yapılan içerik analizi sonucunda ulaşılan kodlar, alt temalar ve temalar Tablo 2'de sunulmaktadır.

Tablo 2.Ulaşılan Kodlar, Alt Temalar ve Temalar

\begin{tabular}{|c|c|c|}
\hline Ulaşılan kodlar & Ulaşılan alt temalar & Ulaşılan temalar \\
\hline $\begin{array}{l}\text { - Teknoloji } \\
\text { - Cep telefonu } \\
\text { - Bilgisayar } \\
\text { - Sosyal ağlar } \\
\text { - Tablet } \\
\text { - Akıllı tahta }\end{array}$ & $\begin{array}{l}\text { - Teknoloji kullanma } \\
\text { becerileri }\end{array}$ & \\
\hline $\begin{array}{l}\text { - Öz güven } \\
\text { - Açık söz } \\
\text { - Cesaret } \\
\text { - Özgür } \\
\text { - Hak } \\
\text { - Sorgulama }\end{array}$ & • Öz güven artış1 & $\begin{array}{l}\text { • Olumlu profil } \\
\text { değişmeleri }\end{array}$ \\
\hline $\begin{array}{l}\text { - Önbilgilerde artış } \\
\text { - Hazır } \\
\text { bulunurlukta artış } \\
\text { - Kolay öğrenme } \\
\text { - Ufuk açıklığı } \\
\text { - Zihinsel Faaliyet } \\
\text { - Zeki }\end{array}$ & • Öğrenme kapasiteleri & \\
\hline $\begin{array}{l}\text { - Terbiye } \\
\text { - Sayg1 } \\
\text { - Büyüklere sayg1 } \\
\text { • Öğretmene sayg1 } \\
\text { - Paylaşım, } \\
\text { - Okul kültürü } \\
\text { - Sevgi }\end{array}$ & $\begin{array}{l}\text { - Sayg1 ve sevgide } \\
\text { azalma }\end{array}$ & $\begin{array}{l}\text { - Olumsuz } \\
\text { profil } \\
\text { değişmeleri }\end{array}$ \\
\hline $\begin{array}{l}\text { - Paylaşım } \\
\text { - Sosyalleşme } \\
\text { - Oyun }\end{array}$ & $\begin{array}{l}\text { - Sosyalleşmede } \\
\text { problemler }\end{array}$ & \\
\hline
\end{tabular}

\author{
- Sosyal iletişim \\ - Davranıș \\ • Okul kültürü \\ - Arkadaşlik \\ - Teknoloji \\ - Paylaşım \\ - Ben $\quad$ Benmerkezcilik \\ - Saygisiz \\ - Bencil \\ - Ders çalışma \\ - Derse hazırlıklı \\ gelme \\ - Şımarık \\ - Çocuksu \\ - Oyun \\ - Sorumluluk \\ - Sorumluluk \\ - Öğrenme isteği \\ - Kurallara uyma \\ - Hazir \\ - Rahat
}

Araştırmanın geçerlik ve güvenirliği, Yıldırım ve Şimşek (2006: 257-268) tarafindan belirtilenler doğrultusunda gerçekleştirilmiştir. İç geçerlik boyutunda, elde edilen bulgular, katılımcılarla paylaşılmıştır. Katılımcılarla birlikte ulaşılan kodlar ve temalar irdelenmiştir. Dış geçerlik boyutunda, araştırma süreci ayrıntılı olarak açıklanmıştır. Dış güvenirlik kapsamında, araştırmanın yöntemi ve aşamaları açık ve anlaşılır biçimde açıklanmıştır. Veri toplama, işleme, analiz etme, yorumlama ve sonuçlara ulaşma açık şekilde tanımlanmıştır. Araştırmanın ham verileri saklanmaktadır. İç güvenirlik boyutunda, araştırma soruları açık bir şekilde belirtilmiştir. Araştırmacının araştırma sürecindeki konumu açık olarak tanımlanmıştır. Araştırmanın tamamında uzman incelemesi yöntemi işe koşulmuştur. Elde edilen veriler temalar altında toplanarak, okuyucunun kolayca anlayabileceği şekilde sunulmuştur.

\section{Bulgular ve Yorumlar}

Sınıf öğretmenlerinin, ilkokul öğrencilerindeki kişilik, karakter, tutum değişimleri konusundaki fenomenleri tespit edilmiştir. Tespit edilen bu fenomenler, ulaşılan temalar altında sunulmuştur. Yapılan içerik analizi sonucunda iki adet temaya ulaşılmıştır. İlki "Olumlu Profil Değişmeleri” ikincisi "Olumsuz Profil Değişmeleri” olmuştur. Ulaşılan temalar Şekil 1.'de sunulmaktadır.

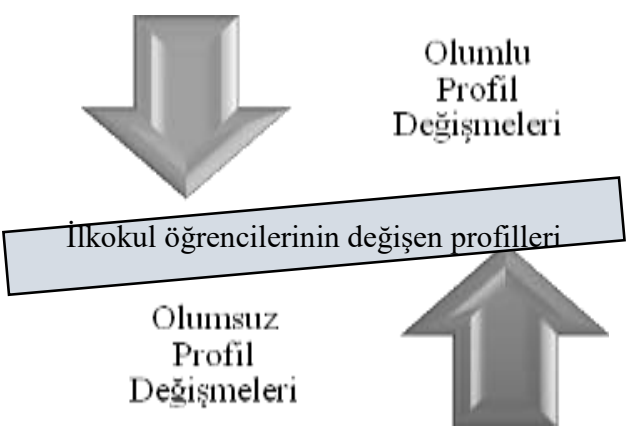

Şekil 1. İlkokul Öğrencilerinin Değişen Profilleri 
Şekil 1 incelendiğinde, ilkokul öğrencilerinin değișen profilleri ile ilgili olarak iki temaya ulaşıldığı görülmektedir. Bunlar, 1. Olumlu profil değişmeleri. 2. Olumsuz profil değişmeleridir. Birinci tema olan "Olumlu Profil Değişmeleri” temasının alt temaları Şekil 2.'de sunulmaktadır.

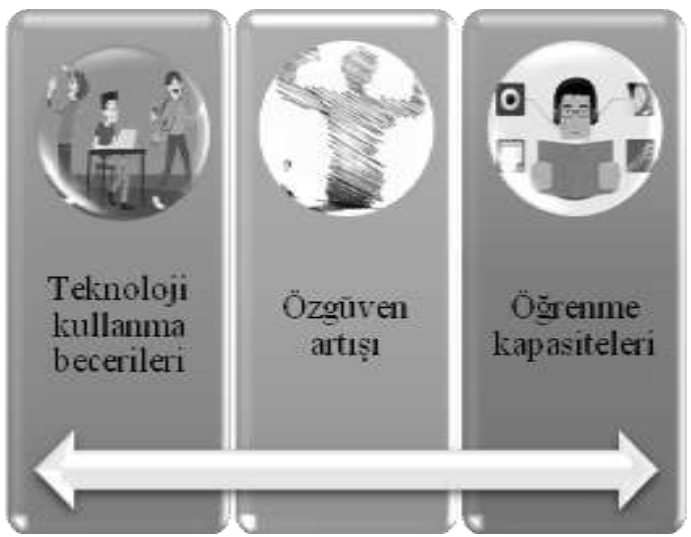

Şekil 2. Olumlu Profil Değişmeleri

Şekil 2 incelendiğinde, "Olumlu Profil Değişmeleri" temasının alt temalarının; teknoloji kullanma becerileri, özgüven artışı, öğrenme kapasiteleri olduğu görülmektedir. İkinci tema olan "Olumsuz Profil Değişmeleri”" temasının alt temaları Şekil 3 'te sunulmaktadır.

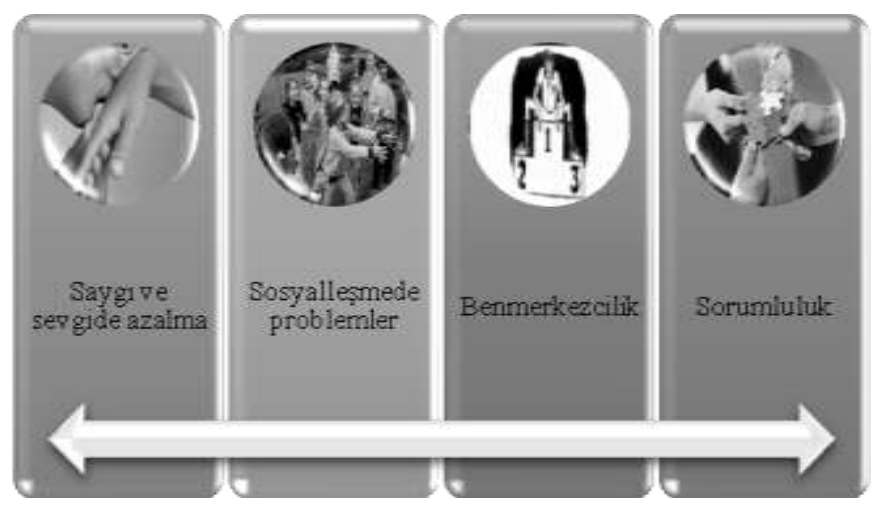

Şekil 3. Olumsuz Profil Değiş̧meleri

Şekil 3 incelendiğinde, "Olumsuz Profil Değişmeleri”" temasının alt temalarının; saygı ve sevgide azalma, sosyalleşmede problemler, benmerkezcilik, sorumluluk olduğu görülmektedir. Bulgular belirtilen temalar ve alt temalar altında sunulmuştur.

\subsection{Olumlu Profil Değişmeleri}

Olumlu profil değişmeleri temasında, günümüz ilkokul öğrencilerinin iyi yöndeki profil değişmeleri incelenmiştir. 2000 yılı öncesi ilkokul öğrencileri ile 2018 yılı ilkokul öğrencileri kıyaslandığı zaman, pozitif yöndeki değişiklikler açıklanmıştır. Olumlu profil değişmeleri teması, alt temalar özelinde açıklanmıştır.

\subsubsection{Teknoloji Kullanma Becerileri}

Olumlu profil değişmeleri temasının ilk alt teması teknoloji kullanma becerileridir. $\mathrm{Bu}$ alt temada, mevcut ilkokul öğrencilerinin teknoloji kullanma becerilerindeki artış vurgulanmıştır. Görüşme yapılan sınıf öğretmenleri(Öğretmen 2, 3, 4, 6, 11, 12, 14, 15, 16), mevcut ilkokul öğrencilerinin teknoloji kullanma becerilerinin geçmişteki ilkokul öğrencilerinden daha iyi olduğunu belirtmişlerdir. Zaman geçtikçe ilkokul öğrencilerinin teknolojiyi daha iyi ve etkin olarak kullandıkları dile getirilmiştir. Konu ile ilgili olarak görüşme yapılan sınıf öğretmenleri şunları dile getirmişlerdir:

Geçmiş yıllardaki (2000 yılı öncesi) öğrenci profili ile şimdiki öğrenci profili arasında çok fark var. Öğrenci teknoloji kullanarak okula geliyor (Öğretmen 2).

Teknoloji kullanma yönünden şimdiki ögrencilerim daha iyi durumdadır (Öğretmen 3).

Günümüzdeki öğrenciler teknolojik aletlerden daha fazla yararlanmaktadır (Öğretmen 4).

Günümüzdeki ögrenciler teknolojiyi daha çok ve güzel kullanıyorlar (Öğretmen 6).

Şimdiki öğrenciler teknoloji hastası (Öğretmen 11).

Günümüzdeki ögrrencilerin teknoloji ile araları çok daha iyi (Ö̈̆retmen 12).

Teknoloji kullanımı olarak çocuklar daha yatkın ve daha beceriklidir (Öğretmen 14).

Her geçen dönemde teknoloji kullanımı artıyor (Öğretmen 15).

Önceden teknoloji imkânları yoktu. Şimdi akullı tahtaların, aklll cep telefonları, fotokopi makineleri eğitim ve ögretime büyük katkılarl olmuştur (Öğretmen 16).

Öğrencilerin teknolojiyi kullanmaları geçmiş yıllara göre daha da gelişmiştir (Öğretmen 17).

\subsection{2. Özgüven Artış1}

Olumlu profil değişmeleri temasının ikinci alt teması özgüven artışıdır. $\mathrm{Bu}$ alt temada, mevcut ilkokul öğrencilerinin özgüvenlerindeki artış vurgulanmıştır. Görüşme yapılan sınıf öğretmenleri (Öğretmen 1, 8, 13, 15), mevcut ilkokul öğrencilerinin, geçmişteki ilkokul öğrencilerine kıyasla daha özgüvenli olduklarını belirtmişlerdir. Konu ile ilgili olarak görüşme yapılan sınıf öğretmenleri şunları dile getirmişlerdir:

Geçmiş yıllardaki (2000 yılı öncesi) ögrrencilerin özgüvenleri yoktu. Şimdi tam tersi. Özgüvenleri çok yüksek (Öğretmen 1).

Günümüzdeki ögrenciler daha özgüvenli (Öğretmen 8).

Şimdiki ögrenciler eski ögrencilere göre daha açık sözlü ve cesaretli (Öğretmen 13).

Her biri özgür olmak istiyor. Daha hareketli, aktif, konuşkan, hakkını sorguluyor ve arıyorlar (Öğretmen 15).

\subsection{3. Öğrenme Kapasiteleri}

Olumlu profil değişmeleri temasının üçüncü alt teması öğrenme kapasiteleridir. $\mathrm{Bu}$ alt temada, günümüz ilkokul öğrencilerinin öğrenme kapasitelerindeki artış vurgulanmıştır. Konu ile ilgili olarak görüşme yapılan sınıf öğretmenleri şunları dile getirmişlerdir:

Teknoloji ilerledikçe öğrenme kapasiteleri daha çok gelişiyor. Birinci sınıfta bazı ögrenciler okuryazar olarak geliyorlar. Sayıları daha kolay okuyor, yazıyorlar. Üç ve dört basamaklı sayıları okuyorlar. Normal ögrenciler birinci 
sınıfa geldiklerinde sayıları ancak okulda ögreniyorlard (Öğretmen 2).

Günümüzdeki ögrenciler daha kolay öğreniyorlar (Öğretmen 6).

Teknolojinin gelişmesi ile ögrencilerin ufku daha açık (Öğretmen 8).

Öğrenciler zihinsel faaliyet olarak oldukça ileri düzeydedir (Ö̈̆retmen 9).

Şimdiki öğrenciler daha zeki daha şımarık. Algıları güçlü. Öğreniyor ama uygulamıyorlar. Akademik olarak başarılılar (Ö̈retmen 11).

Öğrenmeye daha hazır halde geliyorlar (Öğretmen 15).

\subsection{Olumsuz Profil Değişmeleri}

İkinci tema olan “Olumsuz Profil Değişmeleri” temasında, günümüz ilkokul öğrencilerinin olumsuz özellikleri incelenmiştir. 2000 y1lı öncesi ilkokul öğrencileri ile 2018 yılı ilkokul öğrencilerinin kıyaslanması sonucunda, mevcut ilkokul öğrencilerindeki negatif değişmeler açıklanmıştır. Bu tema ulaşılan alt temalar bağlamında incelenmiştir.

\subsubsection{Sayg1 ve Sevgide Azalma}

Olumsuz profil değişmeleri temasının ilk alt teması saygı ve sevgide azalmadır. $\mathrm{Bu}$ alt temada, 2018 y1lı ilkokul öğrencilerinin sayg1 ve sevgi değerlerindeki azalma vurgulanmıştır. Görüşme yapılan sınıf öğretmenleri(Ö̆gretmen 1, 3, 5, 6, 7, 9, 10, 11, 12, 13, 15, 16), mevcut ilkokul öğrencilerinin aile büyüklerine, öğretmenlere daha az saygı ve sevgi duyduğunu belirtmişlerdir. Konu ile ilgili olarak görüşme yapılan sınıf öğretmenleri şunları dile getirmişlerdir:

Geçmiş yıllardaki (2000 yılı öncesi) öğrenciler daha terbiyeli, daha saygılı idi (Öğretmen 1).

Geçmişteki ögrencilerim ögrretmenine ve çevresine karşı daha saygılıydı (Öğretmen 3).

Günümüzdeki ögrrenciler fazla teknolojik araç kullandıkları için Saygl-sevgi değerleri oldukça zayıf (Öğretmen 5).

Öğretmene olan saygı maalesef azaldı (Öğretmen 6).

Geçmişteki ögrrenciler okula ve öğretmene karşı daha saygllıdı (Öğretmen 7).

Büyüklere saygl az (Öğretmen 9).

Öğrenci profili her yll değişim gösteriyor. Daha önceki yıllarda (10-15 yll) ögrenciler daha saygll, sevgi dolu idi (Öğretmen 10).

Şimdiki öğrenciler. Başkalarına karşı saygısız ve bencil (Öğretmen 11).

Okula ve ögretmene karşl sevgi ve saygllarl var tabi ki ama önceki yıllara göre giderek azallyor (Ö̈̆retmen 12).

Geçmiş yıllardaki öğrenciler şimdiki öğrencilerden daha saygllı ve sevgi duyardı (Öğretmen 13).

Paylaşım, saygl, sevgi, okul kültürüne uyumda biraz daha zorlanma fazla oluyor (Öğretmen 15).

Okula ve öğretmene karşı önceden daha fazla saygl ve sevgi vardl. Öğretmenin imkânları daha iyi olduğu için saygl ve sevgi fazla idi. Öğrenciler okuduğunda iş güç sahibi oluyordu. Okumanın imkânları fazla idi. Bu da sevgi ve sayglyı artırıyordu (Öğretmen 16).

\subsubsection{Sosyalleşmede Problemler}

Olumsuz profil değişmeleri temasının ikinci alt teması sosyalleşmede problemlerdir. Bu alt temada, mevcut ilkokul öğrencilerinin sosyalleşmede problemler yaşadığı vurgulanmıştır. Görüşme yapılan sınıf öğretmenleri (Öğretmen 5, 9, 11, 15), mevcut ilkokul öğrencilerinin arkadaşlık kurmada ve bu arkadaşlığı devam ettirmede sıkıntılar yaşadıklarını belirtmişlerdir. Konu ile ilgili olarak görüşme yapılan sınıf öğretmenleri şunları dile getirmişlerdir:

Günümüzdeki ögrrenciler fazla teknolojik araç kullandıkları için paylaşım yok. Sosyalleşmede zayıflar. Oyun oynamayı beceremiyorlar (Öğretmen 5).

Sosyal iletişim becerileri oldukça zaylf (Öğretmen 9).

Davranış olarak başarısızlar (Öğretmen 11).

Paylaşım, saygl, sevgi, okul kültürüne uyumda biraz daha zorlanma fazla oluyor. Arkadaşları ile alışana kadar daha fazla problem yaşlyorlar (Öğretmen 15).

\subsubsection{Benmerkezcilik}

Olumsuz profil değişmeleri temasının üçüncü alt teması benmerkezciliktir. $\mathrm{Bu}$ alt temada, mevcut ilkokul öğrencilerinin benmerkezcilik duygularının arttığı vurgulanmıştır. Görüşme yapılan sınıf öğretmenleri(Öğretmen $5, \quad 9, \quad 11), \quad$ mevcut ilkokul öğrencilerinin aşırı kendini düşünen ve bencil olduklarını belirtmişlerdir. Konu ile ilgili olarak görüşme yapılan sınıf öğretmenleri şunları dile getirmişlerdir:

Günümüzdeki öğrenciler fazla teknolojik araç kullandıkları için paylaşım yok (Öğretmen 5).

Ben duygusu yüksek (Öğretmen 9).

Şimdiki öğrenciler Başkalarına karşı saygısız ve bencil (Öğretmen 11).

\subsubsection{Sorumluluk}

Olumsuz profil değişmeleri temasının dördüncü ve son alt temas1 sorumluluktur. $\mathrm{Bu}$ alt temada, mevcut ilkokul öğrencilerinin sorumluluk bilincinde azalma olduğu vurgulanmıştır. Görüşme yapılan sınıf öğretmenleri (Ögretmen 3, 8, 9, 10, 12, 13, 14), mevcut ilkokul öğrencilerinin verilen görevleri yerine getirmede sıkıntı yaşadıklarını belirtmişlerdir. Ayrıca zora gelmek istemediklerini söylemişlerdir. Konu ile ilgili olarak görüşme yapılan sınıf öğretmenleri şunları dile getirmişlerdir:

Algılamaları, ders çalışmaları, derse hazırlıklı gelmeleri geçmişteki öğrencilerimde daha iyiydi (Öğretmen 3).

Değişen hayat şartları ile çocuklar daha şımarık. Geçmişteki (2000 yılı öncesi) ögrenciler dersi daha dikkatli dinliyorlardl. Şimdiki çocuklar daha çocuksu. Ders dışında daha çok oyuna önem veriyorlar. Teknoloji ailelerinde bilinçsiz olarak kullanması bunun etkisini gösteriyor (Öğretmen 8).

Sorumluluk yönüyle zaylf olmaları dikkat çekici (Öğretmen 9).

Önceki yıllarda daha çok ögrenme isteği vardl. Verilen bir kitap istekle okunurdu. Şimdiki çocuklar teknolojiye doymuş. 
Kitap vb. okumaya hevesi pek olmayan bir profildeler (Öğretmen 10).

Kurallara uyma konusunda çok rahatlar. Sorumluluk sahibi değiller. Araştırma konusunda zayıflar. Hazır bulmak hoşlarına gidiyor (Öğretmen 12).

Geçmiş yıllardaki ilkokul öğrencileri ögrenmeye karşı daha istekliydiler (Öğretmen 13).

Daha rahatlarına düşünler. Öğretmenin kendilerini ders konusunda sıkmasını istemiyorlar (Öğretmen 14).

\section{Sonuç ve Öneriler}

Sınıf öğretmenlerinin, ilkokul öğrencilerindeki kişilik, karakter, tutum vb. değişimlerini belirlemek amacıyla fenomenoloji türünde gerçekleştirilen bu araştırmada, sınıf ögretmenlerinin konu ile ilgili fenomenleri, ulaşılan temalar altında sunulmuştur. Bu araştırma sonucunda iki adet temaya ulaşılmıştır. Ulaşılan temalar ve alt temalar şunlardır: Olumlu profil değişmeleri: teknoloji kullanma becerileri, özgüven artışı, öğrenme kapasiteleri. Olumsuz profil değişmeleri, sayg1 ve sevgide azalma, sosyalleşmede problemler, benmerkezcilik, sorumluluk.

Yapılan araştırma sonucunda ulaşılan ilk sonuç, günümüz ilkokul öğrencilerinin geçmişteki ilkokul öğrencilerine kıyasla teknoloji kullanma becerilerindeki artıştır. Görüşme yapılan sınıf öğretmenleri, günümüz ilkokul öğrencilerinin teknoloji kullanma becerilerinin geçmişteki ilkokul öğrencilerinden daha iyi olduğunu belirtmişlerdir. Zaman geçtikçe ilkokul öğrencilerinin teknolojiyi daha iyi ve etkin olarak kullandıkları dile getirilmiştir. Yapılan araştırma sonucuyla benzerlik gösterecek şekilde Pedró (2006: 10-13) ve tarafından yapılan araştırma sonucunda günümüz öğrencilerinin özellikle basılı olmayan dijital kaynaklara erişme, önceleri dinlenmeye ayrilan sürenin günümüzde bilgisayar ve internet ile geçirildiğini ve son olarak çoklu ortamların yazılı ürünlerden daha değerli olduğu belirtilmiștir. Deveci, Açık, Gülbayrak, Demir, Karadağ ve Koçdemir (2007) tarafından yapılan araştırma sonucunda ilköğretim öğrencilerin \%26'sının cep telefonu kullandığ1, \%11'inin kendine ait cep telefonunun olduğu, \%59,3'ünün bilgisayar kullandığını ortaya çıkmıştır. Öğrencilerin \%99,9’u televizyon izlediği vurgulanmıştır. Bennett, Maton ve Kervin (2008: 784) ve Lei (2009: 95 tarafından yapılan çalışmalarda 21. Yüzyıl öğrenci özellikleri arasında teknoloji kullanma becerisindeki artış vurgulanmıştır. Günümüz bilgi, teknoloji ve iletişim çağıdır. İlkokul öğrencilerimizin bu çağa uygun olarak, teknolojik araçları kullanma becerilerindeki artışın iyi bir durum olduğu söylenebilmektedir.

Araştırma sonucunda ortaya çıkan bir diğer sonuç, ilkokul öğrencilerindeki özgüven artışıdır. Görüşme yapılan sınıf öğretmenleri günümüz ilkokul öğrencilerinin, 2000'li yılların ilkokul öğrencilerine kıyasla daha özgüvenli olduklarını belirtmişlerdir. Benzer bir sonuca Ezmeci ve Dilekmen (2016) tarafından ulaşılmıştır. Ezmeci ve Dilekmen (2016) yaptıkları araştırma sonucunda, ilkokul birinci sınıf öğrencilerinin özgüven düzeylerini yüksek seviyede bulmuşlardır. İlkokul öğrencilerinde bulunan öz güvenin ailelerin yetiştirme tarzıyla ilişkili olduğu düşünülmektedir. $\mathrm{Bu}$ durumda ailelerin, öz güvene sahip çocuklar yetiştirdikleri ve bundan yıl sonra bugüne göre daha öz güvenli yetişkinler görülebileceği söylenebilmektedir.
Araştırma sonucunda ulaşılan olumsuz profil değişmelerinin ilki ilkokul öğrencilerinin sayg1 ve sevgi değerlerindeki azalmadır. Görüşme yapılan sınıf öğretmenleri, günümüz ilkokul öğrencilerinin aile büyüklerine, öğretmenlere daha az sayg1 ve sevgi duyduğunu belirtmişlerdir. Oysaki MEB (2015: 2)İlkokul Hayat Bilgisi Dersi Öğretim Programında öğrencilere kazandırılması gereken değerler arasında saygı ve sevgi yer almaktadır. Ayrıca adı geçen programda saygı ve sevgi ile alakalı kazanımlar da yer almaktadır. İlkokul öğrencilerindeki sayg1 ve sevgi değerlerinin azalması geleceğimiz toplumu açısından sakıncalı bir durumdur. Birbirine saygı ve sevgi duymayan insanların robottan farksız olacağ1 düşünülmektedir. Bireylere sayg1 ve sevgi duyulmadı̆̆ı zaman, iletişimde problemler yaşanması kaçınılmaz olabilmektedir.

Araştırmanın bir diğer sonucu, ilkokul öğrencilerinin sosyalleşme problemleridir. Görüşme yapılan sınıf öğretmenleri, günümüz ilkokul öğrencilerinin arkadaşlık kurmada ve bu arkadaşlığı devam ettirmede sıkıntılar yaşadıklarını belirtmişlerdir. Araştırma sonucuyla benzerlik gösterecek şekilde Yılmaz (2012: 121), günümüz öğrencileri ile sağlıklı bir sınıf iletişimi oluşturmanın daha farklı yöntemler gerektirdiğini vurgulamıştır. Benzer bir şekilde Pedró (2006: 12), günümüzde teknolojik araçların daha çok sosyalleşme olanakları sunmasına rağmen, fiziksel izolasyon ve yalnızlığın daha da arttığını dile getirmiştir. Yine benzer bir şekilde Chen ve Peng, (2008: 467),aşırı internet kullanan öğrencilerin, interneti az kullananlara göre daha fazla içe dönük, yalnız, fiziksel olarak hasta ve depresyona girmiş olduklarını belirtilmiştir. Ulaşılan sosyalleşme problemleri sonucu ile ilgili olarak, 2000'li yıllarda ve öncesinde oynanan sokak oyunları akla gelmektedir. 2018 yılında sokaklarda oyun oynayan çocuk görmek neredeyse imkânsız hale gelmektedir. İlkokul öğrencileri evlerinde bilgisayar, cep telefonu, televizyon ile meşgul olmaktadır. Bu durum ise sosyalleşme problemlerine sebep olmaktadır.

Bir başka araştırma sonucu, ilkokul öğrencilerindeki benmerkezciliktir. Görüşme yapılan sınıf öğretmenleri, günümüz ilkokul öğrencilerinin aşırı kendini düşünen ve bencil olduklarını belirtmişlerdir. İlkokul öğrencilerinin paylaşım duygusundaki azalma vurgulanmıştır. Bencillik kültürel değerlerimizle bağdaşmayan bir durumdur. Benmerkezcilik ve bencillik yardımlaşmayı, paylaşmayı yok eden unsurlardır. Ulaşılan sonuç çerçevesinde, 2040 yılında, 2018 yılından daha bencil, benmerkezci ve paylaşımsız yetişkinler göreceğimiz düşünülmektedir.

Araştırma sonucunda ulaşılan son sonuç, ilkokul öğrencilerinde sorumluluk duygusunun azalmasıdır. Görüşme yapılan sınıf öğretmenleri, günümüz ilkokul öğrencilerinin verilen görevleri yerine getirmede sıkıntı yaşadıklarını belirtmişlerdir. Ayrıca zora gelmek istemediklerini söylemişlerdir. Oysaki MEB (2015: 2) İlkokul Hayat Bilgisi Dersi Öğretim Programında öğrencilere kazandırılması gereken değerler arasında sorumluluk yer almaktadır. Yaşam, sorumluluklar almayı ve bu sorumlulukları en iyi şekilde yerine getirmeyi gerekmektedir. Sorumluluk duygusu gelişmeyen insanların ise hayatını ilgilendiren önemli kararları ya alamamakta ya da yanlış kararlar alabilmektedir.

Araştırmanın ortaya koyduğu sonuçlar bağlamında, değişen ilkokul ögrenci profilleri kapsamında şu öneriler getirilmiştir: 
- Fatih projesi kapsamında tüm dersliklere akıllı tahta yerleştirilmesi amaçlanmaktadır. Ancak 2018 yılı itibariyle henüz akıllı tahta bulunmayan ilkokul derslikleri bulunmaktadır. İlkokul öğrencilerinin teknoloji kullanma becerilerini geliştirmesi açısından akıllı tahta bulunmayan siniflara akıllı tahta tak1lması önerilmektedir.

- Milli Eğitim Bakanlığı tarafından sadece lise öğrencilerine ücretsiz olarak tablet dağıtılmıştır. İlköğretim öğrencilerinin teknoloji kullanma becerilerinin geliștirilmesi bakımından ilköğretim öğrencilerine de ücretsiz olarak tablet dağıtılması önerilmektedir.

- İlkokul öğrencilerindeki öğrenme kapasitelerindeki artış kapsamında, öğrencilerin öğrenmelerinin artırılmasına yönelik etkinliklerin geliştirilmelidir. Bu konuda Nunley tarafından geliştirilen basamaklı öğretim uygulamaların etkili olacağı düşünülmektedir. $\mathrm{Bu}$ şekilde her bir öğrenci kendi öğrenme kapasitesini sonuna kadar kullanmış olacaktır.

- Bir başka önemli araştırma sonucu, ilkokul öğrencilerinin sevgi ve saygı değerleri yönünden düşük seviyede olmalarıdır. Bu konuda sorumluluk öncelikle velilere, sonra öğretmene, tüm topluma düşmektedir. $\mathrm{Bu}$ değerlerin kazandırılmasına yönelik olarak sevgi ve sayg1 konulu kitapların okunması, bu konudaki örnek olayların öğrencilere yaşatılması, bu konuyla ilgili filmler izletilmesi önerilmektedir.

- Mevcut ilkokul öğrencilerinin benmerkezci, paylaşımdan uzak oldukları görülmektedir. Öğrencilerin bu olumsuz özelliklerinin ortadan kaldırılmasında sosyalleşme önemli bir role sahiptir. Öğrencilerin sosyalleşmelerini sağlamak amacıyla, öğretmenlerin ve velilerin; çocuk oyunları, ailelerce piknik gibi etkinlikler düzenlemeleri faydalı olacaktır.

- $\mathrm{Bu}$ araştırma ilkokul öğrencilerinin profillerini belirlemeye yönelik bir çalışmadır. Yapılacak araştırmalarla, ortaokul, lise ve üniversite öğrencilerinin değişen profilleri incelenebilir.

\section{Kaynakça}

Aydın, B. (2003). Bilgi toplumu oluşumunda bireylerin yetiştirilmesi. Pamukkale Üniversitesi Ĕ̆itim Fakültesi Dergisi, 14(14), 183-190.

Bennett, S., Maton, K. \& Kervin, L. (2008). The 'digital natives' debate: a critical review of the evidence. British Journal of Educational Technology, 39(5), 775-786.

Boyd, D. M. \& Ellison, N. B. (2007). Social network sites: definition, history, and scholarship. Journal of ComputerMediated Communication, 13(1), 210-230.

Büyüköztürk, Ş., Kılıç Çakmak, E., Akgün, Ö. E., Karadeniz, Ş. \& Demirel, F. (2012). Bilimsel araştırma yöntemleri (12. Bask1). Ankara: Pegem Akademi.

Can, İ. (2015). Değişen türkiye'de egitimin islevlerini yeniden düsünmek: velilerin ilk ve orta okullardan beklentileri üzerine bir araştırma. Selçuk Üniversitesi Edebiyat Fakültesi Dergisi, 34, 247-266.

Chen, Y. F, \& Peng, S. S. (2008). University students' internet use and its relationships with academic performance, interpersonal relationships, psychosocial adjustment, and self-evaluation. CyberPsychology \& Behavior, 11(4), 467-469.

Christensen, L. B., Johnson, R. B. ve Turner, L. A. (2015). Araştırma yöntemleri desen ve analiz (Çev. Edt: Ahmet Aypay). Ankara: Anı Yayıncılık.

Creswell, J. W. (2013). Nitel araştırma yöntemleri: beş yaklaşıma göre nitel araştırma ve araştırma deseni (3. Baskıdan Çeviri) (Çev. Edt.: Mesut Bütün, Selçuk Beşir Demir). Ankara: Siyasal Kitabevi.

Erol, N. (2011). Toplumsal değişme ve eğitim: temel ilişkiler, çelişkiler, tartışmalar. Gazi Akademik Bakış, 5(9), 109122.

Ezmeci, F. \& Dilekmen, M. (2016). İlkokul birinci sınıf öğrencilerinin özgüvenleri. Erzincan Üniversitesi Ĕgitim Fakültesi Dergisi, 18(1), 513-534.

Feltz, D. L. (1988). Self-confidence and sports performance. Exercise and Sport Sciences Reviews, 16(1), 423-458.

Fidan, F. \& Fidecioğlu, A. (2010). Kutsallıkla tutsaklık arasında bir meslek öğretmenlik: sorunlar, yaklaşımlar ve beklentiler. Adiyaman ÜniversitesiSosyal Bilimler Enstitüsü Dergisi, (5), 146-160.

Fraenkel, J. R., Wallen, N. E. \& Hyun, H. H. (2011). How to design and evaluate research in education (8th Edition). New York: McGraw-Hill.

Glesne, C. (2012). Nitel araştırmaya giriş. (Çev.: A. Ersoy ve P. Yalçınoğlu). Ankara: Anı Yayıncılık.

Gliner, J. A., Morgan, G. A., \& Leech, N. L. (2015). Uygulamada araştırma yöntemleri: desen ve analizi bütünleştiren yaklaşım (Çev. Ed.: Selahattin Turan). Ankara: Nobel Yayın Dağıtım.

Gündoğar, F. (2014). Değişen eğitim anlayışı 1şı̆̆ında değişen öğretmen yetiştirme programları üzerine düşünceler. Diyalog Interkulturelle Zeitschrift Für Germanistik, 2(1), 118-127.

Günüç, S., Odabaş1, H. F. \& Kuzu, A. (2013). 21. yüzyıl öğrenci özelliklerinin öğretmen adayları tarafından tanımlanması: bir twitter uygulaması. Ĕgitimde Kuram ve Uygulama, 9(4), 436-455.

Jones, E. G. (2000). Neurowords 8 plasticity and neuroplasticity. Journal of the History of the Neurosciences, 9(1), 37-39.

Lei, J. (2009). Digital natives as preservice teachers: What technology preparation is needed?. Journal of Computing in Teacher Education, 25(3), 87-97.

Merriam, S. B. (2013). Nitel araştırma desen ve uygulama için bir rehber (Çev. Ed.: Selahattin Turan). Ankara: Nobel Akademik Yayıncılık.

Milli Eğitim Bakanlığı Talim ve Terbiye Kurulu Başkanlığı (2015). Ilkokul hayat bilgisi dersi (1, 2 ve 3. Sinflar) ögretim programı. Ankara.

Monereo, C. (2004). The virtual construction of the mind: The role of educational psychology. Interactive Educational Multimedia, 9, 32-47. 
Parlar, H. (2012). Bilgi toplumu, değișim ve yeni eğitim paradigmas1. Yalova Üniversitesi Sosyal Bilimler Dergisi, 2(4). 193-209.

Patton, M. Q. (2014). Nitel araştırma ve değerlendirme yöntemleri (3. Baskıdan Çeviri). (Çeviri Editörleri: Mesut Bütün, Selçuk Beşir Demir). Ankara: Pegem Akademi.

Pedró, F. (2006). The new millennium learners: challenging our views on ICT and learning. Inter-American Development Bank.

Prensky, M. (2001). Digital natives, digital immigrants. On the Horizon, 9(5), 1-5.

Prensky, M. (2009). H. sapiens digital: from digital immigrants and digital natives to digitalwisdom. Innovate: Journal of Online Education, 5(3), 1-10.

Şahin, M. C. (2009). Yeni binyılın öğrencileri’nin özellikleri. Anadolu Üniversitesi Sosyal Bilimler Dergisi, 9(2), 155172.

Tompkins, A. W. (2007). Brain-based learning theory: an online course design model.Unpublished Dissertation, Liberty University.

Türk Dil Kurumu (2018). Güncel türkçe sözlük.www.tdk.gov.tr

White, L. J. \& Castellano, V. (2008). Exercise and brain health-implications for multiple sclerosis.Part 1Neuronal Growth Factors. Sports Medicine, 38(2), 91100. https://doi.org/10.2165/00007256-200838020-00001.

Yıldırım, A. \& Şimşek, H. (2006). Sosyal bilimlerde nitel araştırma yöntemleri (6. baskı). Ankara: Seçkin Yayıncilık.

Yılmaz, M. (2012). Değiş̧en öğrenci, değişen öğretmen. DEM Dergi, 2(6), 120-123. 

